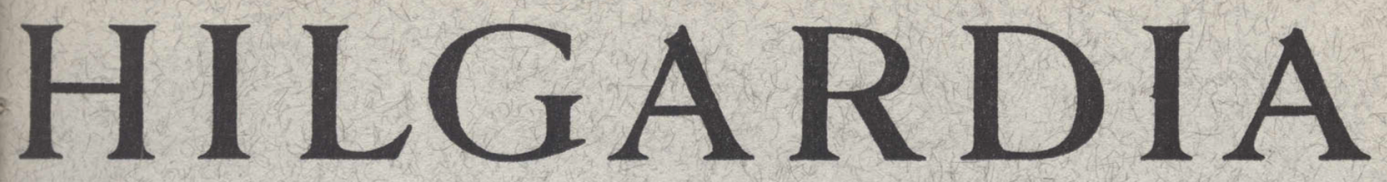

A Journal of Agricultural Science Publisbed by the California Agricultural Experiment Station

\title{
HISTOLOGY OF PITUITARY, ADRENAL, AND REPRODUCTIVE ORGANS IN NORMAL CATTLE AND CATTLE WITH LOWERED REPRODUCTIVE EFFICIENCY
}

\author{
PERRY T. CUPPS, R. C. LABEN, \\ and \\ S. W. MEAD
}

UNIVERSITY OF CALIFORNIA • BERKELEY, CALIFORNIA 
Histological changes occurring in the pituitaries and ovaries of normal cows during the estrous cycles have been described. Changes in the testes, adrenals, pituitaries, and ovaries were found in animals with lowered fertility. These changes indicate that the lowered fertility is associated with several different conditions in the different organs and the animals have been tentatively placed in groups according to histological conditions found. 


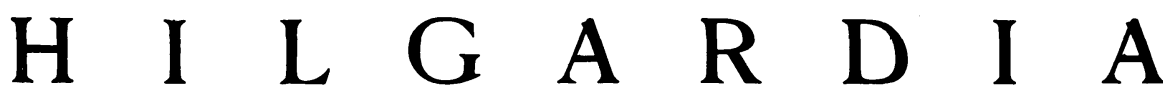

A Journal of Agricultural Science Published by

the California Agricultural Experiment Station

VoL. 29

DECEMBER, 1959

No. 9

\section{HISTOLOGY OF PITUITARY, ADRENAL, AND REPRODUCTIVE ORGANS IN NORMAL CATTLE AND CATTLE WITH LOWERED REPRODUCTIVE EFFICIENCY}

\author{
PERRY T. CUPPS, ${ }^{2}$ R. C. LABEN, ${ }^{3}$ and S. W. MEAD
}

\section{INTRODUCTION}

Histological changes in the pituitary, adrenal, ovary, uterus, and testis have been reported in many sterile and low-fertility cattle. Many of the functional relationships between these changes and infertility, however, have not yet been evaluated.

Several conditions in low-fertility cattle have been described in the literature. Garm $(1949)^{5}$ described a condition that he called cystic ovarian degeneration. Among cows so affected he found animals with constant estrus, animals with regular cycles, animals with irregular cycles, and animals without estrus. Casida and Chapman (1951) discussed factors affecting the incidence of cystic ovaries in Holstein cows. They diagnosed cystic ovaries in cows on the basis of the size of the follicle and estrous behavior. Wiltbank, Tyler, and Casida (1953) described the incidence of follicular atresia in different sire lines of Holstein cows. Unruptured follicles with diameters of $25 \mathrm{~mm}$ or more were defined as atretic large follicles. In this experiment they divided the cows into groups similar to those described by Garm (1949). Tanabe and Casida (1949) and Tanabe and Almquist (1953) described a high incidence of early embryonic mortality in repeat breeder cows and heifers. In their studies 24 per cent of the heifers and 40 per cent of the cows failed to become pregnant; embryos were normal in 21 per cent of the cows at 34 days after conception, and in 31 per cent of the heifers 30 days after conception. Jubb and McEntee (1955b) described the formation of luteal cysts in follicles that did not rupture. Moss, Sykes, and Wrenn (1956) described abnormalities consisting of distinctive nodules in the endo-

\footnotetext{
${ }^{1}$ Submitted for publication January 26, 1959.

${ }^{2}$ Professor Animal Husbandry and Animal Husbandman in the Experiment Station, Davis.

${ }^{3}$ Associate Professor Animal Husbandry and Associate Animal Husbandman in the Experiment Station, Davis.

"Professor Animal Husbandry and Animal Husbandman in the Experiment Station, Davis.

${ }^{5}$ See "Literature Cited" for citations referred to in the text by author and date.
} 
metrium and changes in the uterine glands. They found an increased incidence of the changes in one group of low-fertility animals.

Hypoplasia of the testis has been reported by many investigators. The condition was found to be accompanied by a decrease in sperm concentration and an increase in number of abnormal forms. Cupps, Laben, and Mead (1954) found changes in the adrenal gland of some low-fertility bulls. Hancock (1949a) described a specific abnormality of sperm associated with infertility in Friesian bulls. He also described sterility in Guernsey bulls whose semen differed from that found in Holsteins (1949b).

Hammond (1927) described normal changes in the follicle and corpus luteum associated with the various stages of the estrous cycle. He found a steady growth of the follicle during the metestrus and diestrus, followed by an accelerated growth in late proestrus and estrus. He found that the corpus luteum reached maximum size about the eighth day following heat. It remained this size until three days before the next heat, when it began to diminish rapidly. Cole (1930) found that the follicle destined to ovulate at the next heat attained a diameter of 14 to $15 \mathrm{~mm}$ by nine days postestrus. The mature corpus luteum had a maximum diameter of 20 to $25 \mathrm{~mm}$, which remained unchanged until the twentieth day of the cycle.

Jubb and McEntee (1955a) reviewed the literature on the pituitary. In an extended study they described two kinds of basophilic cells: the large basophils (beta cells), associated with thyrotropic activity; and the small basophils (delta cells), changing with the various stages of the estrous cycle. They claimed that the beta cells are primarily concerned with thyrotropic activity, but also described an altered beta-type basophil associated with both the "cystic ovary syndrome" in cows and the degeneration of seminiferous epithelium in bulls. They suggested that the delta cells of the pars distalis proper are concerned with the synthesis and release of luteinizing gonadotropin. In their series the delta cells of the pars tuberalis and zona tuberalis did not show the cyclic activity found in the cells of the pars distalis during the estrous cycle, and suggested the possibility that the delta cells of this region might be the site of the origin of the folliclestimulating hormone. Cupps, Laben, and Mead (1956) found differences in the small basophil (delta) cells of some cows during pregnancy and in sterile cows with irregular cycles and nymphomania.

The experiment reported here, begun in 1951, was designed to study the histological conditions of the pituitaries, adrenals, ovaries, uteri, and testes of sterile or low-fertility animals as they were eliminated from the University herd or from coöperators' herds. Except for a few normal animals from coöperators' herds, the animals had complete reproductive histories, and their health had been under the supervision of staff veterinarians from the School of Veterinary Medicine. For comparisons, the experiment was later modified to include histological changes during the estrous cycle in normal open cows, and assays of the pituitaries for gonadotropic hormones. In addition, organs from normal bulls were collected for comparison with those of low-fertility bulls. This paper presents the histological and assay data on the organs from these animals. 


\section{MATERIALS AND METHODS}

The experimental animals are discussed in groups established arbitrarily on the basis of gross characteristies and histological study. There was some overlapping among groups, and further study may lead to some regrouping, reclassification, or combining. The present grouping is as follows:

1. Twenty normal cows. These animals had calved at least once, and before slaughter they were checked for normal estrous cycles, 3 to 8 per cow. Designating estrus as day 1 , these cows were slaughtered on the following days: day 1,2 cows ; day 2,3 cows ; day 3,2 cows ; day 4,1 cow ; day 5,1 cow; day 6,2 cows; day 8,1 cow; day 10,1 cow ; day 11,1 cow ; day 12,1 cow; day 16,1 cow ; day 17,1 cow; day 20,1 cow ; day 22,2 cows. The cow slaughtered on day 20 had previously shown a 21 -day cycle, and the cows slaughtered on day 22 had previous cycles of 22 and 23 days.

2. Nine pregnant cows. Slaughter of these animals covered most of the gestation period-from 30 days following conception to less than a week before they were due to calve.

3. Sixty-three sterile cows. These animals had been bred 8 to 27 times without conception and had histories of irregular cycles. They are treated as a single group because histological studies and pituitary assays failed to reveal any consistent characteristics that could be used in subdividing them. It is possible that these animals represent sterility due to more than one cause, but criteria for classification are not evident at present. Except for animals with constant estrus and animals with regular cycles they represent animals similar to those described by Garm (1949) and Wiltbank, Tyler, and Casida (1953).

4. Nine cows with nymphomania. These cows had shown nymphomania for 3 to 9 months at the time of slaughter, and their behavior indicated continued active symptoms. Four cows had corpora lutea in the ovary at slaughter; four did not; ovaries from the other cow were not collected.

5. Two cows with endometritis. Endometritis in these animals was diagnosed by the University veterinarians with a recommendation for disposal. One was a Holstein and one was a Jersey.

6. Five normal bulls. Two were Holstein, and three were Jersey.

7. Five bulls with hypoplasia of testis, normal libido. Four were Holstein, and one was Jersey.

8. Four bulls with small tumors of the fascicular zone of the adrenal. One was a Holstein; two were Guernsey; and one was a Hereford.

9 . Five bulls with reduced libido. Four were Jersey; one was a Guernsey. 10. Five bulls with complete degeneration of the seminiferous tubules of the testis. Four were Jersey, and one was a Guernsey.

Histological methods used in the studies were as follows: Transverse sections about $2 \mathrm{~mm}$ thick were removed from the pituitary, dividing the anterior and posterior lobes into two parts each. The central section was immediately placed in fixative. In later parts of the experiment the remaining portions of the gland were frozen immediately, lyophilized in the frozen state, and stored in a freezer until assayed. The connective tissues surround- 
ing the anterior and posterior lobes were removed, and the anterior lobe was ground and suspended in sterile physiological saline for assay.

Both adrenals were removed at slaughter, and cut in cross sections about $5 \mathrm{~mm}$ thick. A cross section was removed from the narrow portion of the notch of the left adrenal and fixed for comparative studies. Any portion of the cut surfaces of the gland that appeared abnormal on gross examination was processed for histological examination.

When a corpus luteum was present, a thin section was taken through its greatest diameter and placed in fixative. A section of the ovary containing the largest follicle was placed in fixative for one hour. The section was divided again in a manner to allow cross sections to be taken from its greatest diameter for histological studies. Small sections of the uterus or testis were fixed at time of slaughter.

All tissues were fixed in formol-zenker and processed by the paraffin technique. Sections from the pituitary were stained with acid fuchsin, acid violet, and methyl green according to the Severinghaus (1932) method, and with the periodic acid Schiff (PAS) stain. The Severinghaus stain allows detailed cytological study of the cells ; Schiff's stain is superior for studying the granulation of the basophilic cells. Sections from the other tissues were stained with hemotoxylin-eosin-azure II.

Motility of semen was estimated on a percentage basis, concentration was determined by counting in a hemocytometer, and the percentages of live sperm and abnormal forms were counted from smears stained with eosin and fast green.

Fructose was measured by the method of Mann (1948), and citric acid by the method of Saffran and Denstedt (1948).

Follicle-stimulating hormone was assayed by the method of Steelman and Pohley (1953) except that the HCG and glandular material was injected once daily.

Luteinizing hormone was assayed by the method of Greep, Van Dyke, and Chow (1941).

\section{RESULTS}

\section{Pituitary}

\section{Histological Changes}

Introduction. Several different terms have been used to describe the basophilic cells found in the anterior lobe of the pituitary gland of cattle. Hall (1938) distinguished two types of basophils in cattle glands: "strong" and "weak" types, according to their relative affinity for hemotoxylin. He described the "strong" basophils as being smaller and more rounded than the "weak." Garm (1949) used the same basic terminology for cattle, and described modified cells of the two basic types in abnormal cows. Cupps, Laben, and Mead (1954) used the terms "large beta" and "small beta" for these two kinds of cells. Jubb and McEntee (1955a) adapted to cattle pituitaries the terms used by Halmi $(1950,1952)$ for rat pituitaries, and 
designated the "large," or "weak," type of basophil as beta cells, and the "small," or "strong," type as delta cells.

Catchpole (1949) adapted the Periodic acid-leucofuchsin method for staining glycoprotein to the study of cellular granules in the pituitary. On the basis of solubility properties and physiological correlates he considered that a part of the material staining positively with the above method was folliclestimulating hormone. Using the stain for glycoprotein and the morphological changes in the cells following various treatments, Purves and Griesbach $(1951,1954,1955)$ and Griesbach, et al. (1957) divided the basophilic cells of the rat pituitary into thyrotrophes (beta cells) and two kinds of gonadotrophes (delta cells). Purves and Griesbach believe that the gonadotrophes secreting F.S.H. are located in the periphery of the rat's anterior lobe and the gonadotrophes secreting L.H. are located in the central region of the lobe. Farquhar and Rinehart (1954a, 1954b), using photomicrographs obtained with the electron microscope, also divided the basophilic cells into thyrotrophes and two types of gonadotrophes. Recently Ross, Bahn, and Schmit (1958), studying the Periodic acid-Schiff reactive material in the rat pituitary, found that the material could be extracted from the glands with acetone. Glands that had been extracted still contained the gonadotropins, and the extracted material did not cause a gonadotropic response. They concluded that the acetone-extractable material giving a positive reaction was a glycolipid. Maximow and Bloom (1957) still use the following nomenclature for pituitary gland cells: The cells are divided into chromophiles and chromophobes, and the former are divided into Acells, or alpha cells, for cells staining with eosin, acid fuchsin, congo red, and azocarmine, and B-cells, or beta cells, for those staining with analine blue, resorcin, hematoxylin, and mucicarmine.

Changes in Normal Cows. The discussion in this paper is limited to changes of the small basophilic (delta) cells associated with the estrous cycles of normal cows and cattle with different types of reproductive failure. The changes in the delta cells of normal cows during the estrous cycle are shown in figures 1 to 10 . Cyclic activity as shown by these cells consists of increased granulation, followed by a degranulation accompanied by an accumulation of colloid in the acinar-like structures of the gland. The amount of colloid seems to reach a peak before ovulation, followed by a gradual diminution. The amount of stored colloid is minimum from the eighth day until the next cycle of granulation begins. Delta cells were smaller in the cows slaughtered on the tenth, twelfth, and seventeenth days of the cycle than in cows at other stages of the cycle. This decrease in size appeared to be due primarily to a decrease in the amount of cytoplasm without changes in the nucleus. The cells maintain the acinar arrangement, but most of the acini do not contain colloid.

A few days before estrus the delta cells begin to store granules (fig. 9), but the variation among individual cells is great. The granules first appear as very fine pink granules in the cytoplasm of the cells. They gradually enlarge and change to a brighter red. When the process of degranulation 
begins the granules are coarse; after degranulation the cells may contain a few large granules, which stain a brick red color (figs. 1, 2). Since an occasional cell does not degranulate, a few granulated cells may be seen at all stages of the cycle.

In the pregnant cow at 120 days, the delta cells resemble those seen during the cycle, with all stages of granulation and degranulation present in the gland and with a few of the acini containing colloid. At parturition the delta cells are large, but most of them are degranulated and very little colloid is present in the gland.

The incidence of small cysts in the pituitary gland of the various groups of cows is recorded in table 4.

Changes in Sterile Animals. In sterile cows with irregular cycles the histological condition of the delta cells of the pituitary resembled those found in normal cows at comparable stages of the estrous cycle. Cows that had ceased to show cycles had fewer granulated delta cells in the pituitary than did normal cows. During proestrus, colloid was sparse and the histological criteria usually associated with cellular activity were not found (compare fig. 29 with figs. 1 to 10 ). However, individual cells contained granular material that gave a positive reaction with the PAS stain.

The pituitary of a cow with nymphomania, corpus luteum absent from ovary, is shown in figure 33. Histologically this organ resembles the pituitary seen in normal cows just following ovulation. In cows with nymphomania, corpus luteum present, the pituitary histologically resembled those of normal animals.

The pituitaries of normal bulls resemble those seen in cows on the second and third day of the cycle.

In bulls with hypoplasia of the testis and normal libido, many of the delta cells of the pituitary showed hyaline degeneration (fig. 38). The large beta and alpha cells of the pituitaries from these bulls were histologically normal.

In bulls with small tumors in the adrenal gland the condition of the delta cells was variable. In those animals showing a high concentration of sperm in the semen the delta cells were numerous and showed histological evidence of secretory activity (fig. 46). On the other hand, in the bull in this group with the lower concentration of sperm the delta cells were sparse and lacked the histological signs of activity seen in the cells of bulls with high concentrations of sperm.

In the group of bulls lacking libido, one bull had a high concentration of sperm and the delta cells were similar to those found in some of the bulls with adrenal tumors. In the other bulls of the group lacking libido the delta cells were granulated (fig. 42), but colloid was very sparse or absent. The concentration of sperm in the semen of these bulls was normal but concentration may not be indicative of the rate of production, because collecting semen from them was possible only at very long intervals. In bulls of group 10, the delta cells of the pituitary resembled those seen in normal bulls. Figure 43 is from the medullary area of the pituitary from a bull in group 10.

Assay of Gonadotropins. After a section was obtained for histological study from normal cows slaughtered at the same stages of the cycle, portions 
of the pituitary remaining were frozen, lyophilized, and assayed for F.S.H. and L.H.

The F.S.H. assays failed to show any difference in normal cows that could be related to the cycle, and failed to show a difference related to sterility. The variability of the weight of the ovaries of assay animals used for controls was so great that differences due to the injected pituitary material were masked and inconclusive. The ovarian weights from the control assay animals varied as much as 100 per cent from week to week.

TABLE 1

VENTRAL PROSTATE WEIGHT OF HYPOPHYSEC.

TOMIZED MALE RATS INJECTED WITH

LYOPHILIZED PITUITARY

$12.8 \mathrm{mg}$ total dose

\begin{tabular}{|c|c|c|}
\hline Day of cycle & $\begin{array}{l}\text { Number of } \\
\text { pituitaries }\end{array}$ & $\begin{array}{c}\text { Average } \\
\text { ventral prostate }\end{array}$ \\
\hline $1, \ldots \ldots \ldots, \ldots, \ldots, \ldots, \ldots$ & 2 & $\begin{array}{l}w t m g \\
25.3\end{array}$ \\
\hline $2 \ldots \ldots \ldots \ldots \ldots \ldots \ldots \ldots \ldots$ & 3 & 26.9 \\
\hline $3 \ldots \ldots \ldots \ldots \ldots$ & 3 & 46.4 \\
\hline $5 \ldots \ldots \ldots \ldots \ldots$ & 1 & 24.9 \\
\hline $6 \ldots \ldots \ldots$ & 2 & 31.0 \\
\hline $8 \ldots$ & 2 & 48.5 \\
\hline $10 \ldots$ & 2 & 32.4 \\
\hline $11 \ldots \ldots \ldots \ldots$ & 2 & 35.1 \\
\hline $12 \ldots \ldots \ldots \ldots \ldots \ldots \ldots \ldots \ldots \ldots$ & 1 & 26.4 \\
\hline $13 \ldots \ldots \ldots \ldots$ & 1 & 32.0 \\
\hline $16 \ldots \ldots \ldots \ldots \ldots \ldots \ldots \ldots \ldots$ & 2 & 37.7 \\
\hline $17 \ldots \ldots \ldots \ldots \ldots \ldots \ldots \ldots \ldots \ldots$ & 1 & 27.0 \\
\hline $20 \ldots \ldots \ldots \ldots \ldots \ldots \ldots \ldots \ldots \ldots \ldots \ldots$ & 1 & 32.6 \\
\hline $22 \ldots \ldots \ldots \ldots \ldots \ldots \ldots \ldots \ldots \ldots \ldots$ & 1 & 29.4 \\
\hline Cor & .. & 10.6 \\
\hline
\end{tabular}

L.H. assays were run on normal and sterile cows at comparable stages of the cycle (table 1 ). The assays of pituitaries from normal and sterile cows were compared statistically by Student's "T" method. No difference was found in L.H. content of the pituitaries from the two groups of cows ( $t=1.28)$. Analysis of the data by the same method showed a difference between days of the cycle (normal cows $\mathrm{t}=2.23, .05 \%$ level; sterile cows $\mathrm{t}=2.18, .05 \%$ level). Because no difference was found the two groups of data were combined for analysis of variance (table 2 ).

These assays indicate that the pituitary gland contains appreciable amounts of L.H. at all periods of the cycle. High values were found in cows slaughtered at the third and eighth days of the cycle. The high content of L.H. found in these glands corresponds very closely to the periods of the cycle when cells of the corpus luteum are undergoing active hypertrophy. Although the hormone content of the gland may not be indicative of the secretion rate, the changes seen in the corpus luteum indicate that, at least in these two phases of the cycle, the L.H. content of the pituitary is closely related to the growth and differentiation of the corpus luteum. 
Segaloff, Steelman, and Flores (1956) and Lostroh, Squire, and Li (1958) showed that prolactin and growth hormones affect the assay of luteinizing hormone. Whether these hormones would affect the response of the ventral prostate under the conditions of the above assay has not been tested experimentally. The former researchers found that the greater response due to prolactin was as great with 0.1 I.U. as with 1.0 I.U., and suggested that the effect of prolactin was an "all or none" phenomenon. Reece and Turner (1937) found prolactin in the pituitary of cattle at all ages. The width of the tibial epiphyseal cartilage was measured in the rats used for assay. All the pituitaries gave a positive response for growth hormone. To test if the growth hormone in the glands affected the assay for L.H., a simple correla-

TABLE 2

ANALYSIS OF VARIANCE OF L.H. CONTENT

OF THE PITUITARY GLAND

\begin{tabular}{|c|c|c|c|}
\hline Source & D F & M.S. & $\mathbf{F}$ \\
\hline Total. & 108 & & $\ldots$ \\
\hline Between days. & 13 & 450.91 & $4.76^{*}$ \\
\hline Cows within days. & 10 & 331.49 & $3.50^{*}$ \\
\hline Within cows............... & 85 & 9467 & $\ldots$ \\
\hline
\end{tabular}

* Significant at .01 level.

tion was calculated between the width of the tibia and the weight of the ventral prostate. The correlation coefficient was -0.068 , indicating no relationship. These observations indicate that prolactin and growth hormone did not affect the L.H. values.

\section{Ovary}

Histological Changes in Normal Cows. Small tertiary follicles 2 to $3 \mathrm{~mm}$ in diameter are present in the ovary at all stages of the cycle. Growth of the follicles during the estrous cycle was measured by taking the largest diameter of the follicle on the slide after fixation and staining. Growth as measured by diameter is shown in table 3 . From these data it appears that growth occurs in two phases: (1) enlargement from 3 to 8 or $10 \mathrm{~mm}$ from the third to the fifth day of the cycle; further enlargement beginning in late proestrus or early heat and continuing until ovulation. Both phases of growth are accompanied by cell division in the theca interna and granulosa layers of the follicle (fig. 11). Although it has not been measured quantitatively, cell division in the follicles appears to be more frequent during proestrus, estrus, and the following five to six days of the cycle. From the middle of the cycle until the second growth phase starts, the cells of the two layers of the follicle show little or no mitotic activity (figs. 12, 13). In one animal killed the seventeenth day the largest follicle showed a shrinkage of the cells of both layers, indicative of early atresia. It is possible that this shrinkage is a normal 
condition of the follicle at this stage of the cycle, but more information is needed to decide.

In the small tertiary follicle the cells of both layers are very compact (fig. 11). It appears that part of the growth occurring during the cycle is due to an increase in the intercellular space (figs. 12, 13). In the second growth phase there appears to be an increase in vascularity in the theca interna, with a further increase in intercellular space (fig. 14). Some of the cells of the granulosa become more rounded, and their nuclei do not stain so intensely.

TABLE 3

GROWTH OF FOLLICLE AND CORPUS LUTEUM DURING THE ESTROUS CYCLE

\begin{tabular}{|c|c|c|}
\hline Day of cycle & $\begin{array}{l}\text { Diameter of } \\
\text { largest follicle }\end{array}$ & $\begin{array}{l}\text { Diameter of } \\
\text { corpus luteum }\end{array}$ \\
\hline & $m m$ & $m m$ \\
\hline $1 \ldots \ldots \ldots \ldots \ldots \ldots \ldots \ldots \ldots \ldots$ & 12.0 (early heat) & \\
\hline $1 \ldots \ldots \ldots \ldots \ldots \ldots \ldots \ldots \ldots \ldots$ & 18.0 & 9 (from previous cycle) \\
\hline $2 \ldots \ldots \ldots \ldots \ldots \ldots \ldots \ldots \ldots$ & 17.0 (preovulation) & $11 \times 7$ (from previous cycle) \\
\hline$\ldots \ldots \ldots \ldots \ldots \ldots$ & 2.5 & $4 \times 7$ (new corpus) \\
\hline $3 \ldots \ldots \ldots \ldots \ldots \ldots \ldots \ldots \ldots$ & 3.0 & $7 \times 8$ (new corpus) \\
\hline $3 \ldots \ldots \ldots \ldots \ldots \ldots \ldots \ldots$ & 15.0 (atretic) & $\ldots \ldots$ \\
\hline 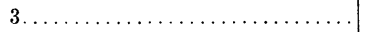 & 3.5 & $2 \times 6$ \\
\hline 5 . & 10.0 & 12 \\
\hline $6 \ldots \ldots \ldots \ldots \ldots \ldots \ldots \ldots \ldots$ & 7.5 & 14 \\
\hline $8 \ldots \ldots \ldots \ldots \ldots \ldots \ldots \ldots \ldots$ & 10.5 & 15 \\
\hline $10 \ldots \ldots \ldots \ldots \ldots \ldots \ldots \ldots \ldots \ldots \ldots$ & 12.5 & $\ldots \ldots{ }^{*}$ \\
\hline $11 \ldots \ldots \ldots \ldots \ldots \ldots \ldots \ldots \ldots \ldots$ & 11.5 & $\ldots \ldots{ }^{*}$ \\
\hline $12 \ldots \ldots \ldots \ldots \ldots \ldots \ldots \ldots \ldots \ldots \ldots \ldots \ldots \ldots \ldots$ & 9.5 & 14 \\
\hline $16 \ldots \ldots \ldots \ldots \ldots \ldots \ldots \ldots \ldots \ldots \ldots$ & 7.5 & $\ldots \ldots{ }^{*}$ \\
\hline $17 \ldots \ldots \ldots \ldots \ldots \ldots \ldots \ldots \ldots \ldots$ & 11.5 & \\
\hline $19 \ldots \ldots \ldots$ & 12.5 & $\ldots \ldots{ }^{*}$ \\
\hline$\ldots \ldots \ldots \ldots \ldots \ldots \ldots$ & 9.5 & 10 \\
\hline $22 \ldots \ldots \ldots \ldots \ldots \ldots \ldots \ldots \ldots \ldots$ & 15.0 & 17 \\
\hline $22 \ldots \ldots \ldots \ldots \ldots \ldots \ldots \ldots \ldots \ldots \ldots \ldots$ & $\ldots$ & 15 \\
\hline
\end{tabular}

* Section of the corpus luteum was cut in a plane that could not be measured accurately.

The major change in the cells of the follicle beginning during proestrus occurs in the theca interna and reaches its maximum during estrus. As these thecal cells increase in size their nuclei become vesicular, the amount of cytoplasm is increased, and they become epitheloid in character (fig. 15). Following heat but before ovulation, the granulosa cells continue to enlarge and the nuclei become more vesicular. In contrast, the thecal cells show signs of regressing from the size seen during heat (fig. 16).

An infiltration of mast cells and eosinophils into the ovary accompanies the second growth phase of the follicle. These cells are found first in the stroma of the ovary, but the eosinophils tend to gather in the thecal layers of the follicle that is destined for ovulation following the heat period.

Following rupture of the follicle the granulosa and theca interna are thrown inte folds, and the granulosa cells become very compact and show signs of luteinization. The basement membrane between the two layers of the follicle breaks down, and the capillaries begin to penetrate the granulosa 
layer. The theca interna and its larger blood vessels are folded within the folds of the granulosa. At this stage there is a massive infiltration of eosinophils beginning in the theca interna and migrating through the granulosa into the cavity of the developing corpus luteum. In the meantime the epitheloid cells of the theca interna become smaller, their cell walls are less distinct, and many of them become spindle-shaped (figs. 17, 18, 19).

Not all of the granulosa cells enlarge at the same rate, and by the sixth day of the cycle some of the cells are fully luteinized (fig. 19). The luteinization of the theca interna cells was first seen in the cow slaughtered the eighth day of the cycle (fig. 20). In the corpus luteum from the cow slaughtered on the tenth day the process was not complete (fig. 21), but by the twelfth day it was impossible to distinguish the two kinds of cells (fig. 22). By the sixteenth day a few of the luteal cells showed histological signs of degeneration and the connective tissue was more prominent (fig. 23). By the twentieth day the degeneration was extensive (fig. 24), and at the next estrus many of the luteal cells were vacuolated (fig. 25).

The young corpus luteum contains a cavity whose location depends on the extent of the growth of the follicle at the rupture point. As the luteal tissue grows, the cavity becomes smaller. In this series of animals the cavity had disappeared by the twelfth day, but some of the corpora lutea from the previous cycle still contained small cavities.

Changes in Sterile Cows. In sterile animals with irregular cycles the ovaries were similar to those seen in normal cows-when the stage of the cycle was known.

In cows with nymphomania, corpus luteum absent, the small follicles were normal histologically. In follicles 12 to $15 \mathrm{~mm}$ in diameter (fig. 37) there is a thickening of the granulosa and theca interna, with a partial luteinization of some of the cells in both layers. An occasional cell in the granulosa had the characteristics of a typical luteal cell. In addition, many of the granulosa cells contained eosinophilic inclusions of various sizes. An occasional heterophil leucocyte was found in these follicles, but the collection of eosinophils found in the normal follicle during estrus and in the early developing corpus luteum was absent. The large follicles, about $25 \mathrm{~mm}$ or more in diameter, resembled atretic follicles. In the cows with behavioral symptoms of nymphomania combined with a corpus luteum in the ovary, the ovaries resembled those of normal cows.

\section{The Adrenal}

The histological characteristics of the normal adrenal of cattle has been described by Cupps, Laben, and Mead (1953), and photomicrographs of the different zones of the adrenal from normal open cows are shown in figures $26,27,28$. Sections of the adrenal glands of cows slaughtered at different stages of the cycle did not show histological differences related to the cycle.

The incidence of myelopoiesis in the adrenal glands of the groups of cows is recorded in table 4. Measurements of the adrenal cortex of cows with different breeding histories are recorded in table 5, and those of individual bulls with different breeding histories are listed in table 6 . 
Figures 34, 35, and 36 were taken from the glomerular, fascicular, and reticular zones of the adrenal from an animal with nymphomania, corpus luteum absent. When compared with glands in the normal cow, the cells of the glomerular zone appear normal, and the cells of the fascicular and reticular zones are hypertrophied, and according to histological criteria

TABLE 4

PERCENTAGE INCIDENCE OF CONDITIONS IN VARIOUS ORGANS OF COWS WITH DIFFERENT REPRODUCTIVE HISTORIES

\begin{tabular}{|c|c|c|c|c|c|c|c|}
\hline \multirow[b]{2}{*}{ Group } & \multirow[b]{2}{*}{$\begin{array}{l}\text { Number } \\
\text { animals }\end{array}$} & \multirow{2}{*}{$\begin{array}{c}\text { Adrenal } \\
\text { myelo- } \\
\text { poiesis }\end{array}$} & \multicolumn{2}{|c|}{ Modified uterine glands } & \multirow[b]{2}{*}{$\begin{array}{l}\text { Pituitary } \\
\text { cysts }\end{array}$} & \multirow{2}{*}{$\begin{array}{l}\text { Cavity } \\
\text { in } \\
\text { corpus } \\
\text { luteum }\end{array}$} & \multirow[b]{2}{*}{$\begin{array}{l}\text { Uterine } \\
\text { infection }\end{array}$} \\
\hline & & & $\begin{array}{l}\text { Coty- } \\
\text { ledonary } \\
\text { area }\end{array}$ & $\begin{array}{l}\text { Intercoty- } \\
\text { ledonary } \\
\text { area }\end{array}$ & & & \\
\hline Normal open cows.... & 20 & 35 & 27 & 10 & 29 & 55 & $7^{*}$ \\
\hline $\begin{array}{l}\text { Sterile cows with irregular } \\
\text { cycles } \ldots \ldots \ldots \ldots \ldots \ldots \ldots\end{array}$ & 63 & 51 & $50 \dagger$ & 22 & 18 & 24 & 21 \\
\hline Sterile cows nymphomania. & 9 & 55 & 0 & 11 & 22 & $50 \ddagger$ & 0 \\
\hline Pregnant cows .......... & 9 & 22 & $\mathbf{0}$ & 11 & 10 & 0 & 0 \\
\hline
\end{tabular}

* Based on 14 cows as diagnosed by a veterinarian. Following treatment these animals had at least one normal pregnancy.

† Based on 44 cows. Cotyledons were not present in the sections from the other individuals.

$\ddagger$ Based on 4 cows, corpora lutea were not present in 4 cows and the ovaries were not collected from one animal.

TABLE 5

ADRENAL CORTICAL WIDTHS OF COWS WITH DIFFERENT REPRODUCTIVE HISTORIES

\begin{tabular}{|c|c|c|c|c|c|}
\hline Group & $\begin{array}{l}\text { Number } \\
\text { cows }\end{array}$ & Breed & $\begin{array}{l}\text { Glomerulosa } \\
\text { width }\end{array}$ & & $\begin{array}{l}\text { Fasciculata and } \\
\text { reticularis width }\end{array}$ \\
\hline & & & $m m$ & & $m m$ \\
\hline Normal. & 20 & Jersey & 0.296 & 2.04 & \\
\hline Irregular cycles. . & $15^{*}$ & Jersey & 0.371 & 2.12 & \\
\hline Nymphomania... & 4 & Holstein & 0.202 & 2.34 & $\begin{array}{l}2 \text { with corpora lutea } \\
2 \text { without corpora lutea }\end{array}$ \\
\hline Nymphomania. & 5 & Jersey & 0.499 & 2.35 & $\begin{array}{l}2 \text { with corpora lutea } \\
2 \text { without corpora lutea } \\
\text { ovaries not collected in } \\
\text { one. }\end{array}$ \\
\hline Pregnant cows.. & 9 & $\begin{array}{l}8 \text { Jersey } \\
1 \text { Holstein }\end{array}$ & 0.254 & 2.08 & \\
\hline
\end{tabular}

* Based on sterile cows slaughtered at the same time as the normal animals.

appear to be active. The glomerulosa of the adrenal of the Jerseys with nymphomania was wider than that of the Holsteins with the same condition. No difference in the width of this zone was found in the normal cows of the two breeds, but there were too few normal and nymphomaniac Holsteins to establish if the difference found in affected animals was significant. The zones of the adrenal were wider in cows with irregular cycles than in normal cows. Histologically the cells of the various zones from the adrenal of the animals with irregular cycles did not appear to be as active as those in 
TABLE 6

ADRENAL AND SEMEN CHARACTERISTICS OF INDIVIDUAL BULLS

\begin{tabular}{|c|c|c|c|c|c|c|c|c|c|}
\hline \multirow{2}{*}{ Group } & \multirow{2}{*}{ Breed } & \multicolumn{2}{|c|}{$\underset{\mathrm{mm}}{\text { Adrenal width, }}$} & \multicolumn{6}{|c|}{ Characteristics of the semen } \\
\hline & & Glom. & F and $R$ & $\begin{array}{l}\text { Conc. } \\
\text { sperm }\end{array}$ & Mot. & Live & Abn. & Fructose & $\begin{array}{l}\text { Citric } \\
\text { acid }\end{array}$ \\
\hline & & & & cu $m m \times 10^{5}$ & per cent & per cent & per cent & $m g / 100 c c$ & $m g / 100 c c$ \\
\hline 6 & Holstein & 0.29 & 1.74 & 14.4 & 76 & 90 & 4.5 & 558 & 625 \\
\hline \multirow{4}{*}{ Normal bulls } & Holstein & 0.38 & 2.09 & 11.4 & 60 & 89 & 3.8 & 706 & 792 \\
\hline & Jersey & 0.26 & 1.84 & 13.1 & 60 & 90 & 4.5 & 559 & 723 \\
\hline & Jersey & 0.28 & 2.38 & 12.7 & 60 & 85 & 11.3 & 558 & 878 \\
\hline & Jersey & 0.27 & 2.27 & 11.7 & 65 & 91 & 3.4 & 760 & 770 \\
\hline Aver. & & 0.30 & 2.06 & 12.66 & 64 & 89 & 5.5 & 628 & 758 \\
\hline 7 & Holstein & 0.16 & 1.75 & 6.8 & 12 & 41 & 41 & 686 & $\ldots$ \\
\hline Normal libido & Holstein & 0.23 & 2.34 & 7.7 & 37 & 56 & 19 & 771 & $\ldots$ \\
\hline \multirow{3}{*}{$\begin{array}{c}\text { Hypoplasia } \\
\text { of testis }\end{array}$} & Holstein & 0.17 & 1.76 & 3.9 & 7 & 20 & 44 & $\ldots$ & $\ldots$ \\
\hline & Holstein & 0.19 & 1.46 & 9.6 & 10 & 29 & 36 & 765 & 609 \\
\hline & Jersey & $0.29^{*}$ & 2.02 & 1.7 & 7 & 35 & 26 & 606 & 577 \\
\hline Aver. & & 0.21 & 1.87 & 5.94 & 17 & 36 & 33 & 707 & 593 \\
\hline 8 & Holstein & $0.23 \dagger$ & 1.22 & 17.3 & 31 & 56 & 19 & 280 & 407 \\
\hline Fascicular & Guernsey & 0.16 & 1.29 & $\ldots$ & .. & .. & .. & $\ldots$ & $\ldots$ \\
\hline \multirow[t]{2}{*}{ Tumor } & Hereford & $0.47^{*}$ & 1.59 & 4.5 & 1 & 8 & 80 & 287 & 450 \\
\hline & Guernsey & 0.21 & 1.07 & $\ldots$ & .. & .. & .. & $\ldots$ & $\ldots$ \\
\hline Aver. & & 0.27 & 1.29 & 10.9 & 16 & 32 & 49 & 284 & 428 \\
\hline 9 & Jersey & 0.30 & 2.38 & 20.6 & 80 & 88 & 5 & 288 & $\ldots$ \\
\hline Adrenal & Jersey & $\ldots$ & $\ldots$ & 13.8 & 30 & 58 & 4 & 290 & $\ldots$ \\
\hline \multirow{3}{*}{ hypertrophy } & Jersey & 0.47 & 1.88 & 10.5 & 42 & 67 & 16 & $75 \S$ & $110 \S$ \\
\hline & Guernsey & 0.37 & 2.12 & $\ldots$ & .. & . & . & $\ldots$ & $\ldots$ \\
\hline & Jersey & 0.46 & 1.99 & $\ldots$ & .. & . & .. & $\ldots$ & $\ldots$ \\
\hline Aver. & & 0.40 & 2.09 & 14.9 & 51 & 71 & 8 & $289 \ddagger$ & $\ldots$ \\
\hline \multirow{5}{*}{$\begin{array}{c}10 \\
\text { Hyaline de- } \\
\text { generation } \\
\text { of testis }\end{array}$} & Jersey & 0.39 & 1.75 & $\ldots$ & .. & .. & .. & $\ldots$ & $\ldots$ \\
\hline & Jersey & 0.56 & 2.75 & .04 & 0 & 0 & 81 & 410 & $\ldots$ \\
\hline & Jersey & 0.28 & 1.43 & $\ldots$ & .. & .. & .. & $\ldots$ & $\ldots$. \\
\hline & Guernsey & 0.42 & 1.74 & 0 & .. & .. & .. & $132 \S$ & $196 \S$ \\
\hline & Jersey & 0.35 & 1.67 & 0 & .. & .. & .. & $\ldots$ & $\ldots$ \\
\hline Aver. & & 0.40 & 1.87 & $\ldots$ & .. & .. & .. & $\ldots$ & $\ldots$ \\
\hline
\end{tabular}

* Includes a distinct fourth zone.

$\dagger$ Not including the tumor area.

$\ddagger$ Exclusive of electrical method.

$\S$ Semen collected with a Marden Electroejaculator.

normal cows (compare figs. $30,31,32$ with figs. $26,27,28$ ) or those of cows with nymphomania (figs. $34,35,36$ ).

In bulls with hypoplasia of the testis, normal fructose concentration, and normal libido, the average width of the glomerular zone (fig. 39) was less than in the normal bulls. The combined widths of the fascicular-reticular zones were variable in these bulls, but on the average were narrower than those of normal bulls.

In three of the four bulls with fascicular tumors (fig. 47) the adrenal cortices were narrow in nontumorous areas. The Hereford bull in this group showed a thickened glomerulosa, which was due to a wide, distinct zone between the glomerulosa and the fasciculata. 
The bulls listed in groups 9 and 10 in table 6 had either a wider glomerulosa (fig. 44) or wider combined zones of the fasciculata and reticularis than did normal bulls. Variability between individuals in the two groups was great in the histological conditions of the adrenal. In some of the bulls the histological condition of the cortical cells indicated activity, and in others the cortical cells appeared to be less active, even though the width of the zones was increased.

\section{Uterus}

Changes in the endometrium of the normal cows during the cycle were not great enough to be of value in determining the stage of the cycle. In a few animals the cells in the superficial part of the compacta were flattened, but this condition was not related to any particular stage of the cycle. Mast cells were found in the endometrium at all stages of the cycle, and the eosinophilic infiltration seen in the maturing ovarian follicle, and developing corpus luteum was also found in the uterus at the same stages of the cycle. However, the number of eosinophils in the uterus was not as large as that seen in the developing corpus luteum.

Modified uterine glands similar to those described by Moss, Sykes, and Wrenn (1956) were found in all groups of cows, with highest incidence in the group with irregular cycles (table 4). These modified glands were also found in the endometrium, adjacent to the cotyledon. Their incidence in this region again was greater in cows with irregular cycles. Sections of cotyledons were not taken from the pregnant cows or the cows with nymphomania.

In one of the two animals with pyometra the superficial layer of the endometrium was filled with heterophils, plasma cells, and lymphocytes. Uterine glands were not present in the superficial layer. In the deeper portion of the endometrium the glandular epithelium was shrunken, and all of the glands were surrounded by dense connective tissue. They resembled the modified uterine glands found in the other groups of animals. In the other animal with pyometra the endometrium was thin and filled with heterophils, but the glands appeared normal.

\section{Testis and Semen}

Hypoplasia was found in the testes of bulls of group 7, figure 40, and many of the sperm obtained from them were abnormal (fig. 41, table 6). Complete degeneration of the tubules occurred in bulls of group 10 (fig. 45).

In the bull with the fascicular adrenal tumor and low concentration of sperm, spermatogenesis was normal up to the formation of spermatids. However, the tubules of the testis from this bull contained only a few developing spermatozoa and those developing did not appear normal. The seminiferous epithelium was normal in the other bulls with fascicular tumors and in the bulls of group 9 .

The interstitial tissue of the testes from all of the bulls was normal except that hypertrophy and hyperplasia were found in two of the bulls with fascicular tumors (fig. 48), and areas of enlarged epitheloid cells were present in the testes from one of the bulls in group 10 (fig. 45). In this 
animal these cells contained smooth, agranular cytoplasm and a pyknotic nucleus. They resembled the nonvacuolated degenerating cells found in degenerating corpora lutea. Libido was variable in this group of bullsvery low in some and normal in others. Only one animal in this group ejaculated enough sperm for a count, and the concentration was only 4,000 sperm per cu mm.

Bulls in groups 8 and 9 produced semen containing a low concentration of fructose. This lowered concentration could not be explained on the basis of the number of sperm in the semen.

\section{DISCUSSION}

The histological changes occurring in the delta cells of the pituitary of normal cows during the estrous cycle indicate a cyclic synthesis and release of material from the gland which is related to the cyclic changes in the ovary.

Except for bulls in group 10, the semen contained high concentrations of sperm when the delta cells showed histological evidence of activity and colloid was abundant. In bulls with decreased concentration of sperm in the semen, the delta cells either showed definite degenerative changes or were heavily granulated with sparse colloid.

Based on histological evidence in the various groups of animals, the activity of the delta cells as shown by granulation, degranulation, and colloid formation appears to be related to growth of the follicles, early development of the corpus luteum, and spermatogenesis. The failure of the spermatogenic response in bulls of group 10 is probably the result of the absence of the seminiferous epithelium. Changes in the delta cells are also related to the adrenal gland. In general, when the fascicular cells of the adrenal evidenced increased activity the delta cells were numerous and also evidenced activity.

These clata indicate that the delta cells begin degranulation and the colloid appears earlier in the cycle and more gradually than was reported by Jubb and McEntee (1955b). Furthermore, they do not support Jubb's interpretation of the function of the delta cells of the pars distalis. He stated that the synthetic activity and degranulation can be interpreted only in terms of the synthesis and release of luteinizing gonadotropin. The L.H. content of the gland does not coincide with the extent of granulation in the delta cells, for L.H. content is as high in the glands showing little granulation as in fully granulated glands. That the L.H. content of the glands reflects hormone secretion is indicated by the morphological changes occurring in the corpus luteum during those phases of the cycle when L.H. content is high. Since the activity of the delta cells is so closely associated with the ovarian activity and spermatogenesis, further experiments should be conducted to determine the physiological role of these cells in the reproductive processes.

Whether the granular material in the cells and the acinar colloid is a hormone is not known. Catchpole (1949) presented data suggesting that a part of this PAS-positive material is the follicle-stimulating principle, and Ross, Bahn, and Schmit (1958) concluded that the material was a glycolipid containing no gonadotropic activity. 
The formation of a cavity appears to be normal in the development of the corpus luteum. The corpus luteum appears to develop in two stages, with luteinization of the granulosa layer occurring largely in the early part of the cycle; marked development of the theca interna cells begins about the eighth day. The physiological significance of the luteinization of the luteal cells from the theca interna is not known. Two observations-the increased growth of the vaginal epithelium at the middle of the cycle (Cupps, 1943) and the frequency that cows show estrus between the eighth and twelfth day of the cycle-indicate that the luteinization of the thecal cells may be associated with estrogen secretion by the corpus luteum.

The infiltration of eosinophils into the uterus, ovary, and developing corpus luteum indicate a possible physiological role for these cellular elements in normal changes in the cycle.

Modified glands adjacent to the cotyledons and in intercotyledonary areas of the uterus were found more frequently in one group of sterile animals than in normal animals. These glands were found in one case of uterine inflammation, but were not seen in another, and they were no more frequent in cows with a history of uterine inflammation than in cows without. These data suggest that uterine inflammation is not the cause of the modification since no other evidence of uterine inflammation was apparent, such as heterophil leucocytes in the uteri of these animals. The modified uterine glands in the uteri of these cows are similar to those described by Moss, Sykes, and Wrenn (1956), Garm (1949), and Hammond (1927). From their occurrence in animals with all types of reproductive histories it is possible that the modification of these glands is caused by occlusion of the glandular opening into the uterine cavity and that the modification is a tissue reaction to the occlusion.

Changes in the adrenal were found in most of the animals with lowered fertility. These changes, as determined histologically, were an increased or decreased width in the various zones, hypertrophy of individual cells in the fascicular and/or reticular zones, undersized cells in all three zones accompanied by histological criteria indicating decreased activity, and the presence of areas of extramedullary myelopoiesis. Whether the changes in the adrenal are another symptom of a basic metabolic derangement or the cause of the changes in the reproductive system, has not been determined. The evidence available - a decrease in seminal sugar and an increase in the concentration of sperm in a bull injected with cortisone-indicates that in some cases the disturbance in the adrenal may be the primary cause. However, the histological condition of the glands indicates that the changes in the adrenal are complex and that changed secretion rates may be present for more than one type of adrenal steroid hormone. If the rates of secretion of the three general types of corticoid hormones are regulated independently it is possible to have 27 different combinations in adrenal secretion rates by the animals. If, in addition, the adrenal secretes an abnormal type of steroid, the combinations could be increased many times. On the other hand, if overproduction of one group of hormones changes the rate of production of the 
others, the possible combinations would be fewer. The histological conditions in the glands indicate that this latter situation is more probable in the affected animals.

Unfortunately, reliable methods are not available for quantitative determination of individual steroids in cattle. Garm (1949) reported increased and decreased amounts of "neutral steroids" in the urine of cows affected with cystic ovarian degeneration. Recently Mixner, Saunders, and Johnston (1957) reported that a group of chromogens, apparently ionone derivatives, in the urine of cows gave positive responses to chemical tests for urinary steroids. They believe that the presence of these ionone derivatives interferes with the urinary measurement of 17-ketosteroids. Until methods for measuring the qualitative and quantitative secretion rates of adrenal steroids become more precise and simple the role of the adrenal in reproduction will be diffcult to study.

\section{SUMMARY}

During the estrous cycle of normal cows the delta cells synthesize PASpositive granules, and then degranulate, and PAS-positive colloid accumulates in the acini of the gland. These changes in the cells are associated with the growth of small follicles, and the growth and rupture of large follicles. The luteinizing hormone content of the gland is high when the cells of the corpus luteum are growing, but it does not appear to be associated with the presence of granular material in the delta cells of the pituitary.

The maturation of the follicle during late proestrus and estrus is associated with an increase in size of the cells of the theca interna.

The corpus luteum develops in two distinct phases, and cells from both the granulosa and theca interna are luteinized. The granulosa cells are luteinized early in the cycle, and the interna cells are rapidly luteinized beginning about the eighth day.

Infiltration of eosinophils into the ovary and uterus occurs at certain times during the estrous cycle.

Low-fertility cows with irregular estrous cycles or absence of cycles showed an increased incidence of extramedullary myelopoiesis in the adrenal gland, an increased width of the adrenal cortex, and an increased incidence of modified uterine glands. As long as these animals were cycling, the pituitary gland and the ovary appeared to be normal. When they ceased to cycle the number of granulated delta cells in the pituitary was reduced.

Cows with nymphomania showed an increased width of the fascicular and reticular zones of the adrenal. The width of the glomerular zone varied in animals affected with this condition. The ovaries from some cows with nymphomania contained corpora lutea, and in others no corpora lutea were present.

Small pituitary cysts were found in all groups of cows studied.

Inflammation of the uterus was accompanied by increased numbers of different kinds of leucocytes.

One group of sterile bulls was characterized by normal libido, normal to high fructose concentration, decreased concentration of sperm, and a high 
percentage of abnormal sperm in the semen. These animals showed hypoplasia of the testis, small adrenal glands, and degenerative changes in the delta cells of the pituitary.

Another group of bulls had small fascicular tumors in the adrenal. The concentration of fructose in the semen was decreased. The concentration of spermatozoa in the semen varied in the individual bulls of this group. Based on histological criteria the concentration of sperm in the individual animals was related to the activity of the adrenal cells and the delta cells of the pituitary.

Another group of bulls showed increased width of the adrenal cortices. As with the above group the concentration of sperm was variable in the individual animals, and the concentration of fructose in the semen was decreased. Libido in this group of bulls was low.

Another group of bulls had a complete degeneration of the seminiferous tubules of the testis. From the appearance of the testis the degenerative process appears to be different from the hypoplasia found in another group of bulls. 

PLATE 1
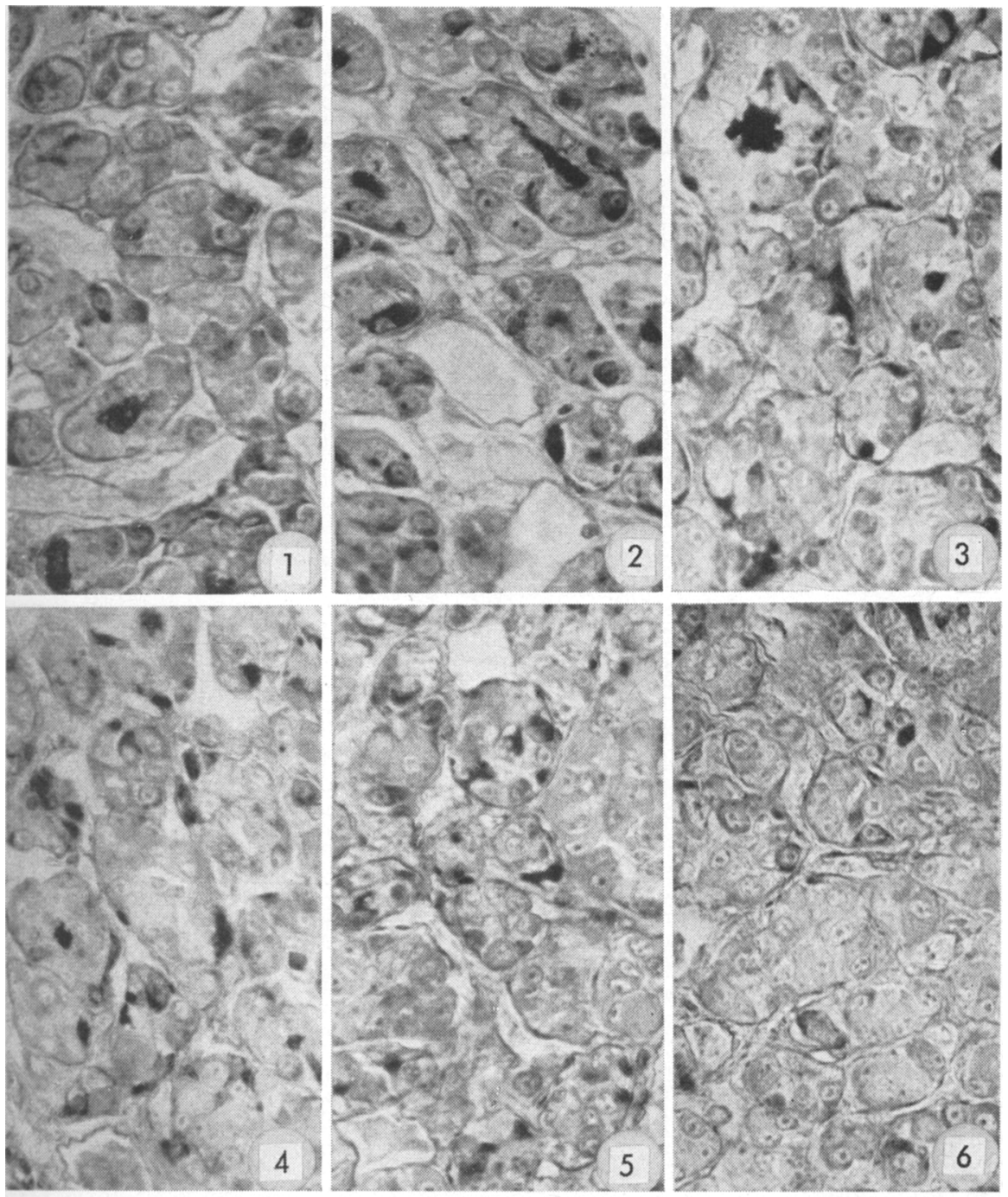

All the tissues in the plates were fixed in Zenker-formol. Pituitaries were stained with the PAS or Severinghaus' method; other tissues were stained with hematoxylin-eosinAzure II.

Figure 1. Pituitary central zone, normal cow in estrus. Degranulation of delta cells and movement of colloid into acini. (PAS $\times 400$.)

Figure 2. Pituitary central zone, normal cow, second day of cycle, post estrus before ovulation. ( $\mathrm{PAS} \times 400$.)

Figure 3. Pituitary central zone, normal cow, second day of eycle, ovulated. (PAS $\times 400$.)

Figure 4. Pituitary central zone, normal eow, third day of cycle. Decreasing colloid within acini with a few delta cells still granulated. (PAS $\times 400$.)

Figure 5. Pituitary central zone, normal cow, fifth day of cycle. (PAS $\times 400$.)

Figure 6. Pituitary central zone, normal cow, eighth day of cycle. $(\mathrm{PAS} \times 400$. $)$ 


\section{PLATE 2}
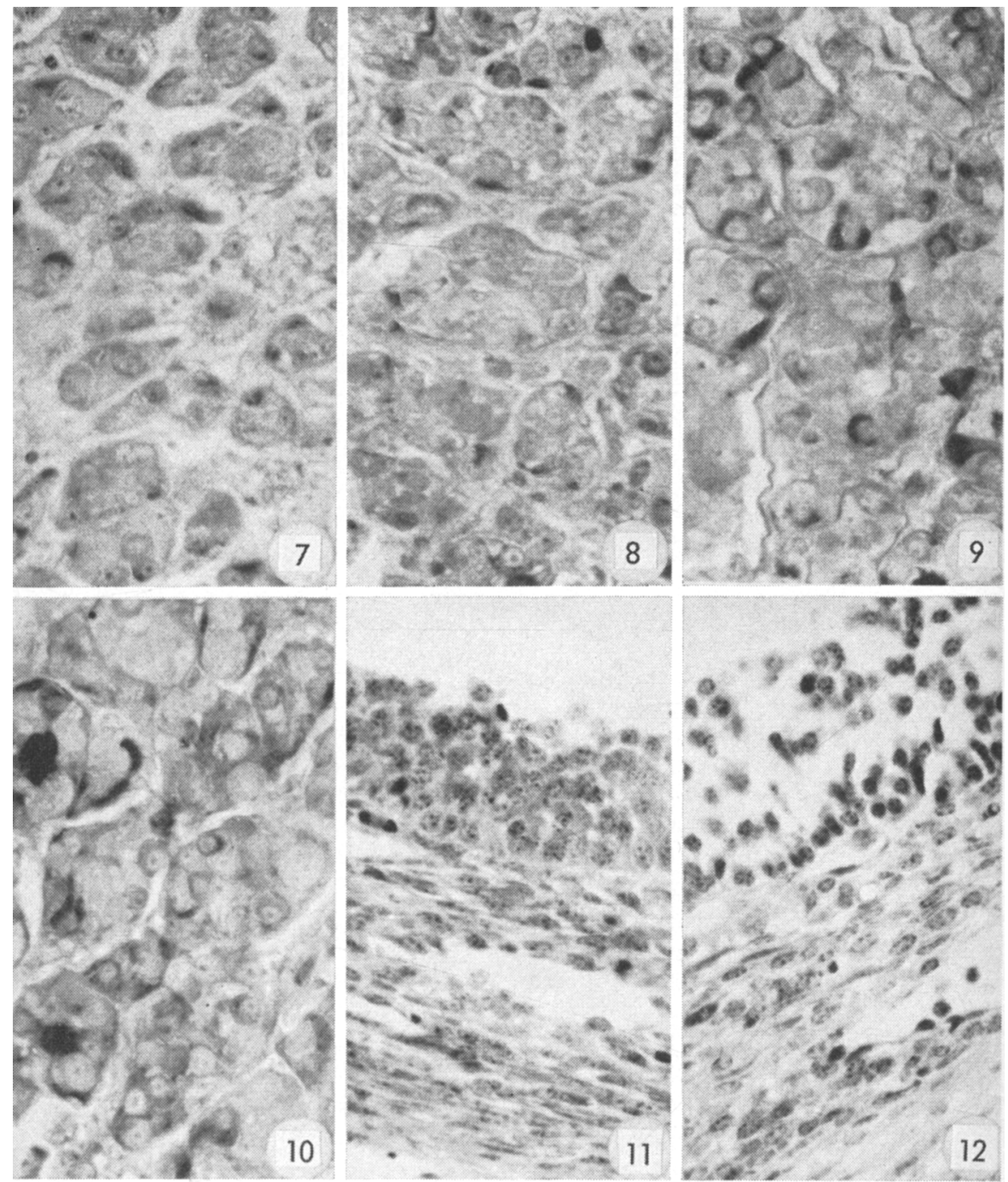

Figure 7. Pituitary central zone, normal cow, tenth day of cycle. (PAS $\times 400$.)

Figure 8. Pituitary central zone, normal cow, twelf th day of cycle. (PAS $\times 400$.)

Figure 9. Pituitary central zone, normal cow, sixteenth day of cycle. Increasing granulation of delta cells. (PAS $\times 400$.)

Figure 10. Pituitary central zone, normal cow, twenty-second day of cycle, proestrus. Degranulation of delta cells, formation of colloid in acini. (PAS $\times 400$.)

Figure 11. Small tertiary follicle, normal cow, third day of cycle. Note cell divisions in granulosa and theca interna. ( $\times 200$.)

Figure 12. Medium size tertiary follicle, normal cow, eighth day of cycle. $(\times 200$. $)$ 
PLATE 3
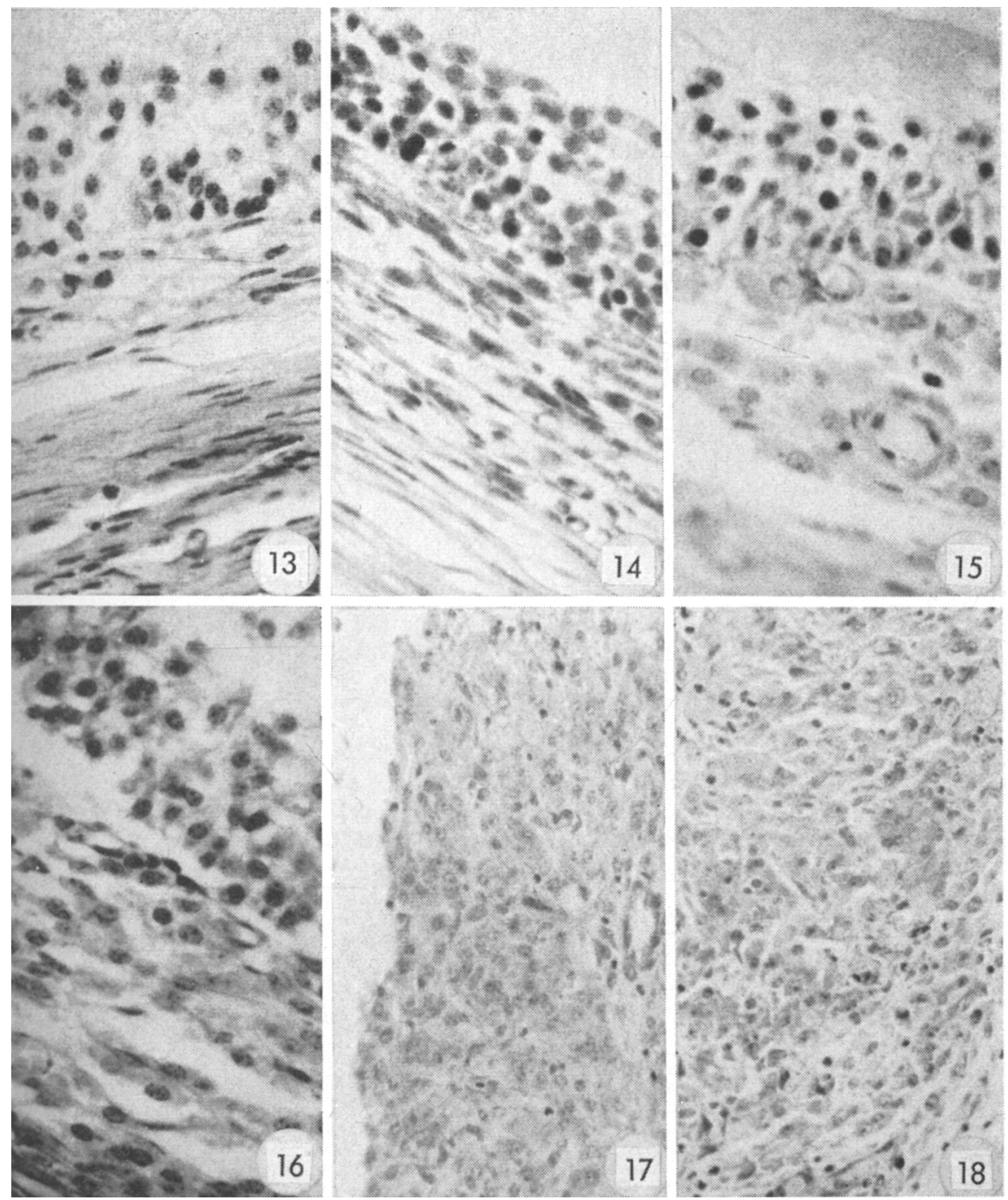

Figure 13. Medium size tertiary follicle, normal cow, eleventh day of cycle. $(\times 200$. $)$

Figure 14. Maturing follicle, normal cow, twentieth day of cycle. $(\times 200$. $)$

Figure 15. Follicle during estrus, normal cow. $(\times 320$. $)$

Figure 16. Preovulatory follicle, normal cow, second day of cycle. $(\times 200$. $)$

Figure 17. Developing corpus luteum, normal cow, second day of cycle; granulosa at left, theca interna at right. $(\times 100$.

Figure 18. Developing corpus luteum, normal cow, third day of cycle. $(\times 100$. 
PLATE 4
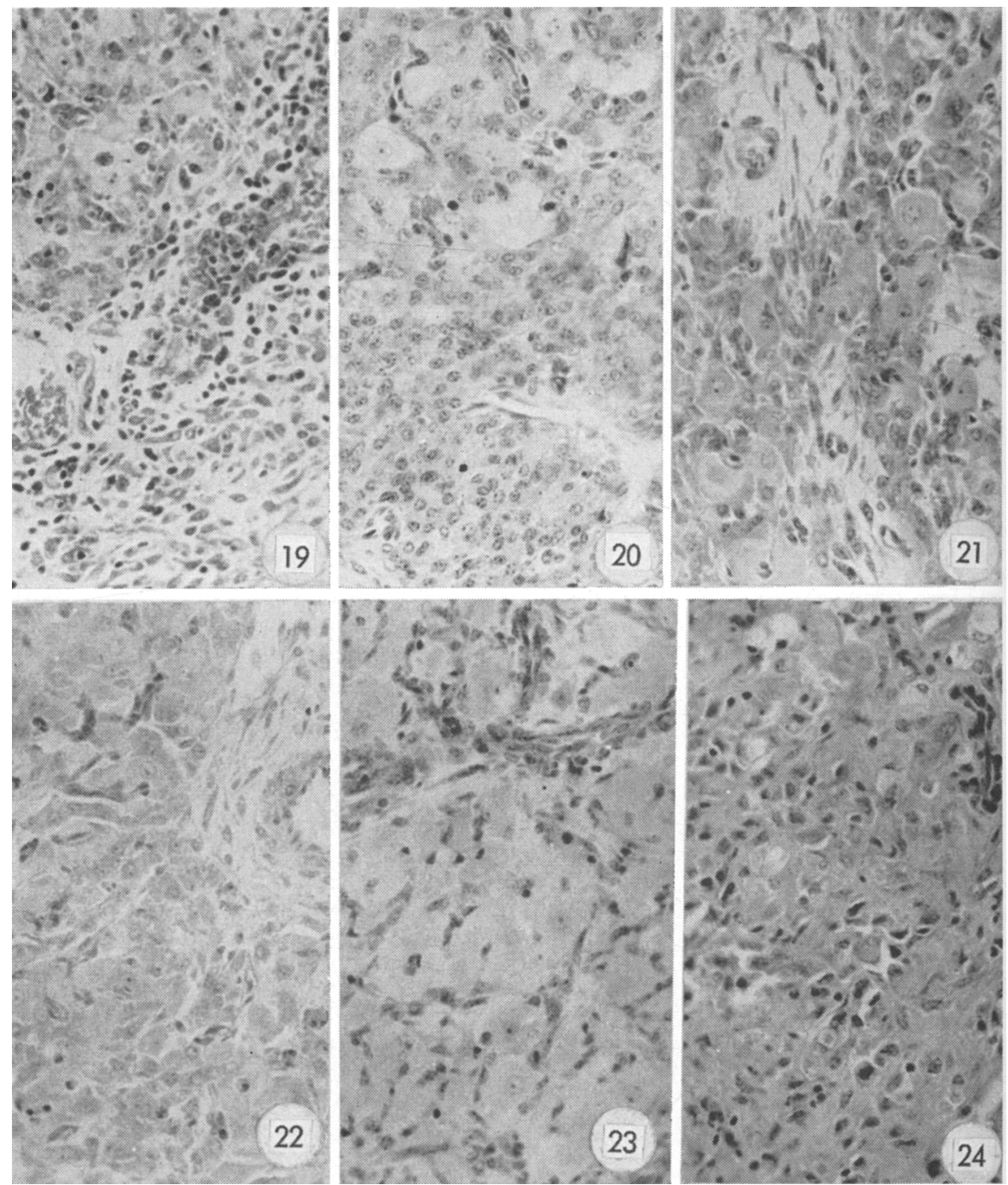

Figure 19. Corpus luteum, normal cow, sixth day of cycle. Granulosa in upper left corner of photograph, interna lower right. $(\times 100$.)

Figure 20. Corpus luteum, normal cow, eighth day of cycle. Luteinization of theca interna cells lower half of photograph $(\times 100$.

Figure 21. Corpus luteum, normal cow, tenth day of cycle. $(\times 100$.

Figure 22. Corpus luteum, normal cow, twelfth day of cycle. $(\times 100$.

Figure 23. Corpus luteum, normal cow, sixteenth day of cycle. $(\times 100$.$) Connective tissue$ elements more prominent; pyknosis of nuclei in some of luteal cells.

Figure 24. Corpus luteum, normal eow twentieth day of cycle. $(\times 100$. $)$ 
PLATE 5
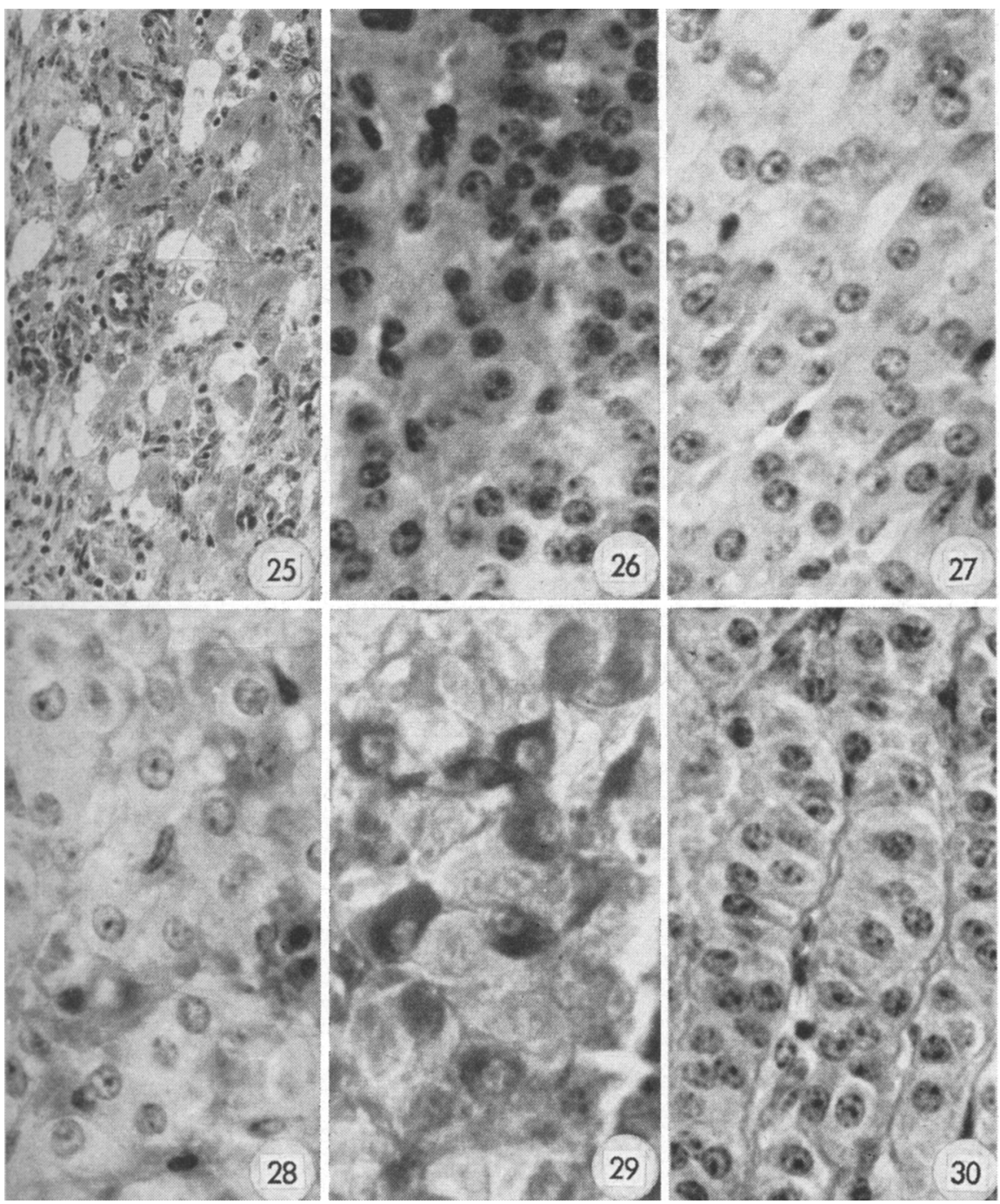

Figure 25. Corpus luteum from preceding eycle, normal cow estrus. $(\times 100$.)

Figure 26. Adrenal glomerulosa, normal open cow. $(\times 620$. $)$

Figure 27. Adrenal fasciculata, normal open cow. $(\times 620$. $)$

Figure 28. Adrenal reticularis, normal open cow. $(\times 620$. $)$

Figure 29. Pituitary central zone, sterile cow without heat periods. (Severinghaus $\times 620$.)

Figure 30. Adrenal glomerulosa, sterile cow; compare with figure 26. $(\times 620$. 


\section{PLATE 6}
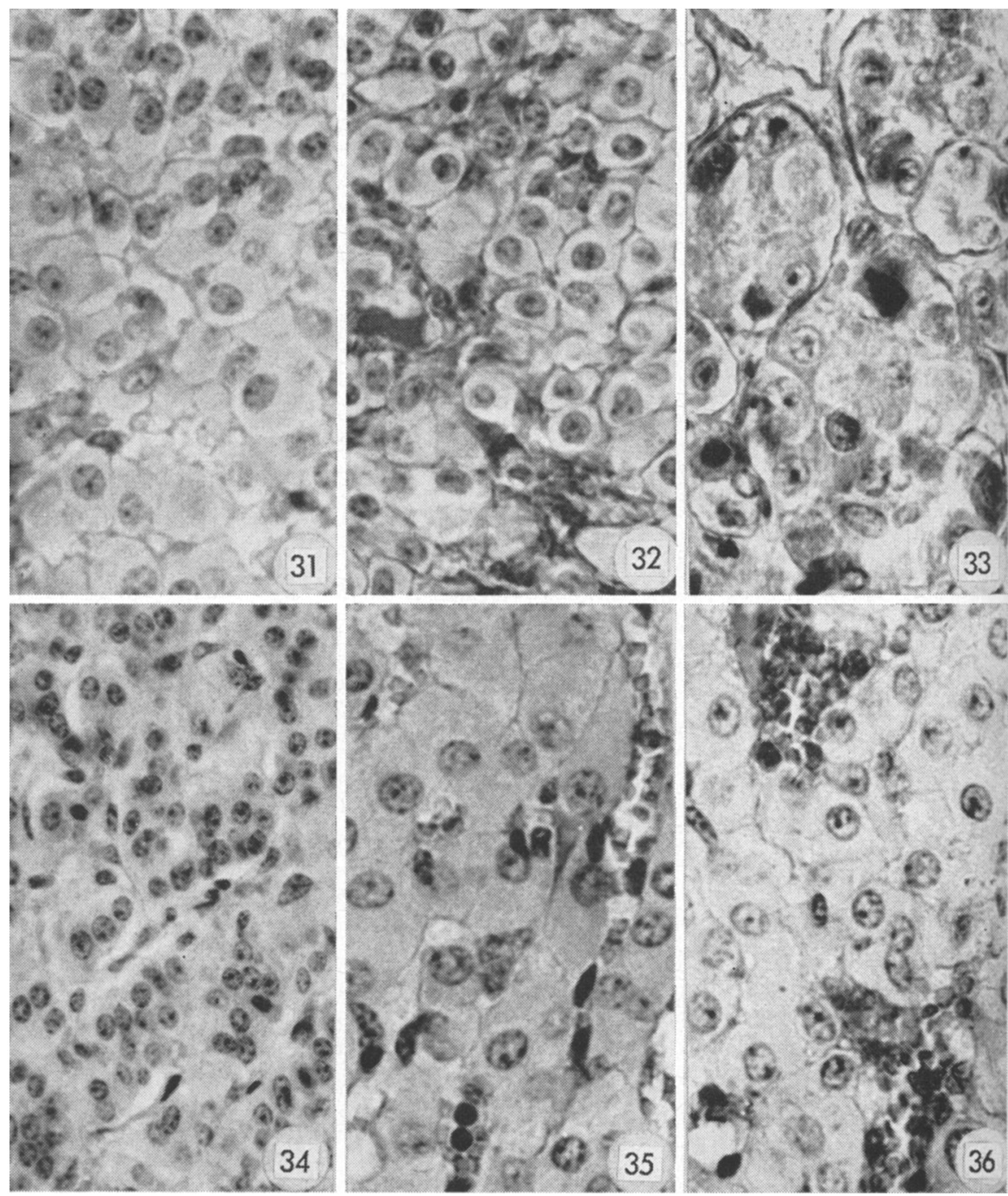

Figure 31. Adrenal fasciculata, sterile cow. $(\times 620$. $)$

Figure 32. Adrenal reticularis, sterile cow. $(\times 620$. $)$

Figure 33. Pituitary central zone, sterile cow with nymphomania; corpus luteum absent from ovary. (Severinghaus $\times 620$.)

Figure 34. Adrenal glomerulosa, sterile cow with nymphomania; corpus luteum absent from ovary. $(\times 400$.

Figure 35. Adrenal fasciculata, sterile cow with nymphomania; corpus luteum absent from ovary. Hypertrophy of cells. $(\times 620$.)

Figure 36. Adrenal reticularis, sterile cow with nymphomania; corpus luteum absent from ovary. $(\times 620$. $)$ 


\section{PLATE 7}
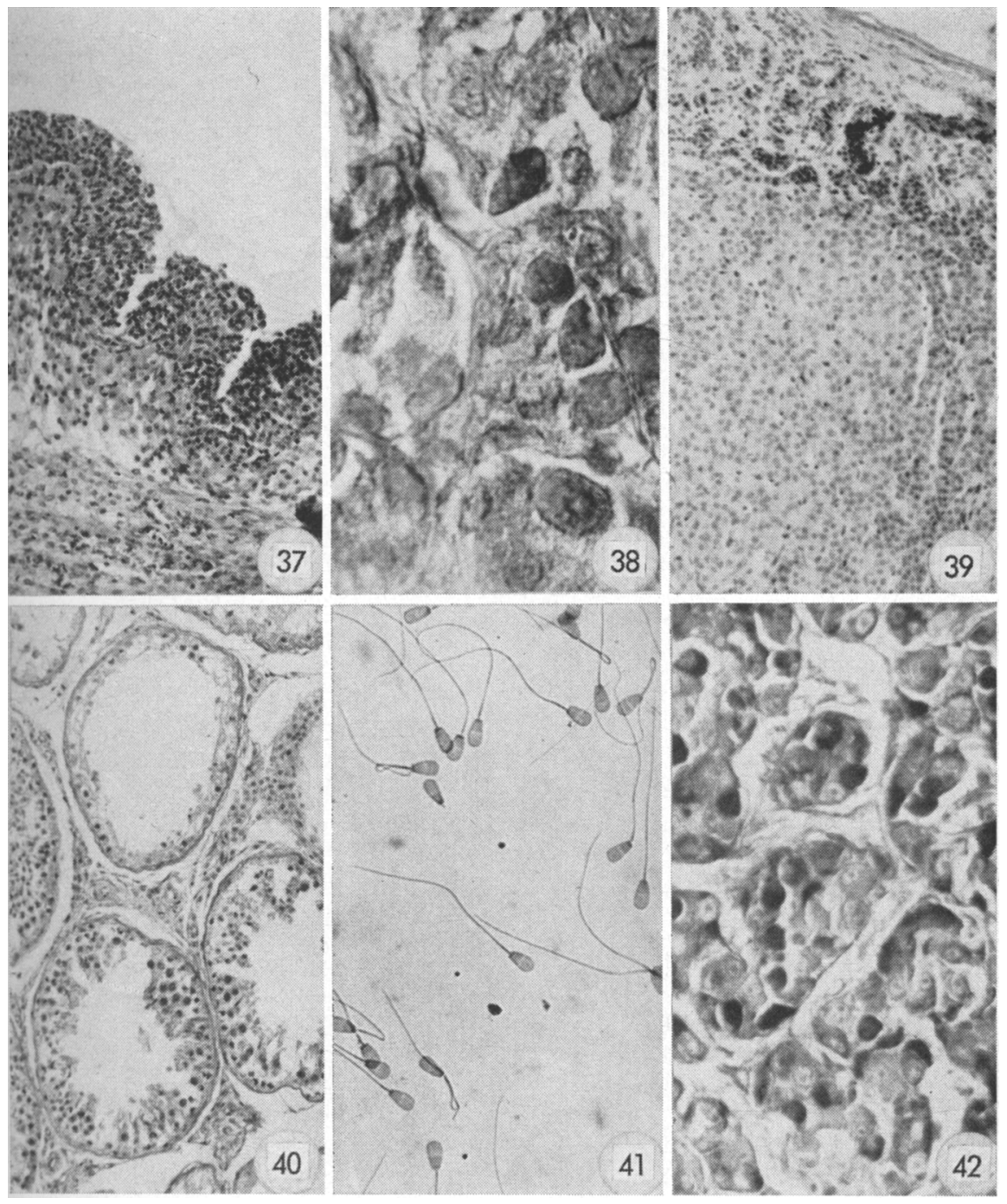

Figure 37. Follicle (12 $\mathrm{mm}$ diameter), sterile cow with nymphomania; corpus luteum absent. $(\times 100$.

Figure 38. Pituitary, sterile bull, normal seminal sugar and hypoplasia of testis. (Severinghaus $\times 620$.)

Figure 39. Adrenal, sterile bull with normal seminal sugar and testicular hypoplasia. $(\times 100$.

Figure 40. Testis, sterile bull with hypoplasia. $(\times 270$. $)$

Figure 41. Spermatozoa, sterile bull with testicular hypoplasia. $(\times 620$.

Figure 42. Pituitary central zone from bull that lacked libido. (PAS $\times 400$.) 


\section{PLATE 8}
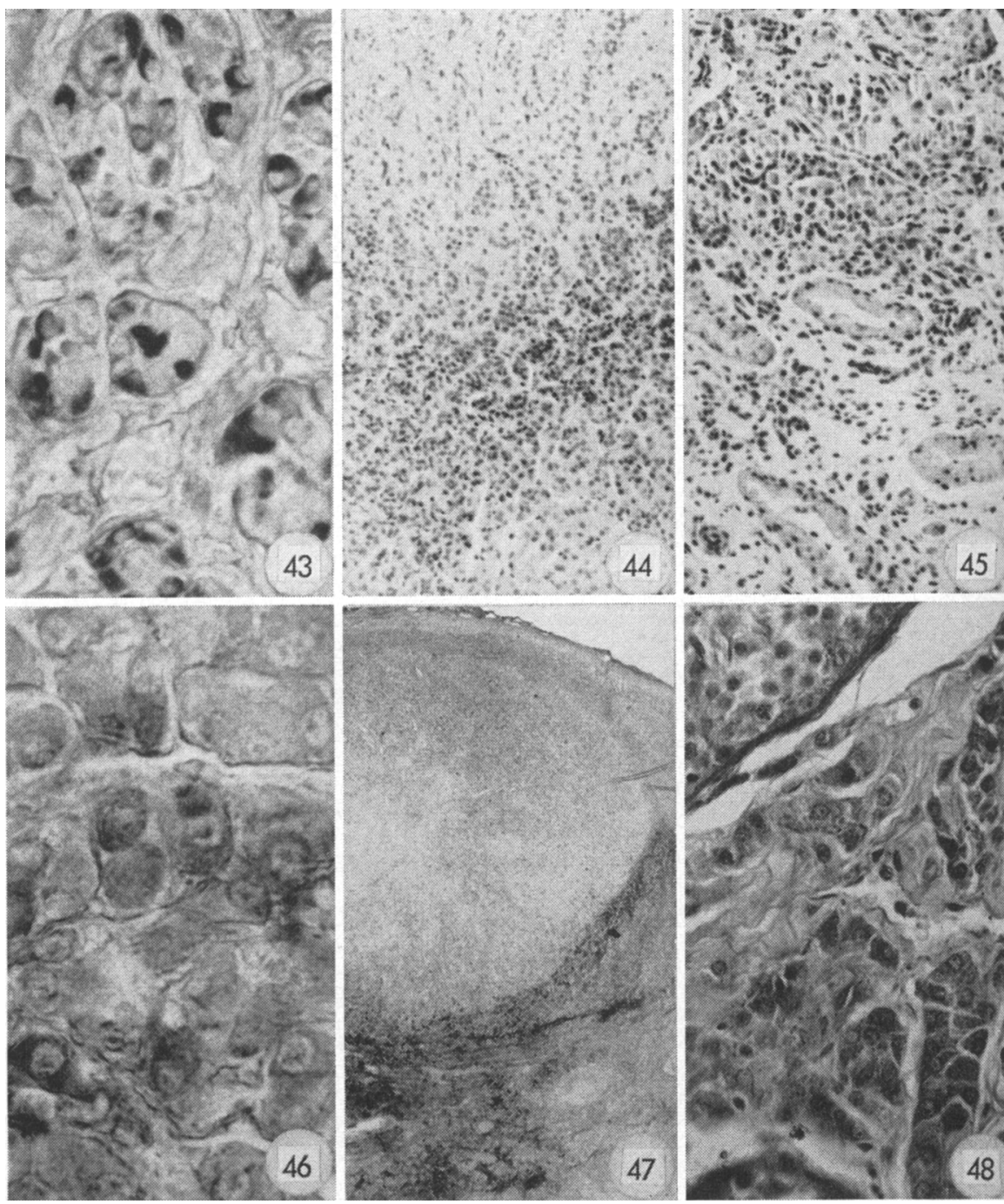

Figure 43. Pituitary central zone, sterile bull with extreme degeneration of seminiferous tubules. $(\times 400$.)

Figure 44. Adrenal, sterile, same bull as above. Note prominent transition zone between glomerulosa and fasciculata. $(\times 100$.

Figure 45. Testis, sterile, bull same as above. Note enlarged epitheloid cells in upper half of photograph. $(\times 100$.

Figure 46. Pituitary central zone, bull with multiple small tumors of the adrenal fasciculata. (Severinghaus $\times 620$.)

Figure 47. Adrenal, bull same as above. ( $\times 12$.)

Figure 48. Testis, bull same as above. A portion of a seminiferous tubule is in upper lefthand corner, the interstitial tissue is shown in the center and lower portion. $(\times 620$.) 


\section{LITERATURE CITED}

Casida, L. E., and A. B. Cuaparan

1951. Factors affecting the incidence of eystic ovaries in a herd of Holstein cows. Jour. Dairy Sei. $34: 1200-05$.

Catchpole, H. R.

1949. Distribution of glycoprotein hormones in the AP gland of the rat. Jour. Endocrinology. 6:218-2:5.

COLE, H. H.

1930. A study of the mucosa of the genital tract of the cow, with special reference to the cyclic changes. Amer. Jour. Anat. 46:261-89.

Cupps, P. T.

1943. A study of the estrous cycle in cattle. Ph.D. Thesis, Cornell University Library.

Cupps, P. T., R. C. LABEN, and S. W. Mead

1953. The occurrence of extramedullary myelopoiesis in the adrenal cortex of the cow. Cornell Veterinarian 43:244-48.

1954. Histology of the pituitary, testis and adrenal in relation to reproduction in the bull. Jour. Dairy Sci. 37:1074-87.

1956. Histology of the pituitaries, adrenals, ovaries and uteri of dairy cattle associated with different reproductive conditions. Jour. Dairy Sci. 39:155-61.

Farquhar, M. G., and J. F. RinEhakT

1954a. Electron microseopic studies of the AP gland of eastrate rats. Endocrinology 54:516-41.

1954b. Cytologic alterations in AP gland following thyroidectomy. Endocrinology 55: 857.

GARM, $\mathrm{O}$.

1949. A study of bovine nymphomania. Acta Endocrinologie, Supplement 3:2.

GREeP, R. O., H. B. VAN DYke, and B. F. ChOW

1941. Use of anterior lobe of prostate gland in the assay of metakentrin. Soc. Expt. Biol. and Mell. Proc. 46:644-49.

Griesbach, W. E., M. E. Beli, and M. Livingston

1957. Changes in pituitary gonadotrophs of the vitamin E-deficient male rat. Endocrinology $60: 729$.

HALL, S. R.

1938. Possible evidence for a second type of basophil in the anterior pituitary of cattle. (abst.) Anat. Rec. 72:123.

HaLmi, N. S.

1950. Two types of basophils in the AP of the rat and their respective cytophysiological significance. Endocrinology $47: 289$.

1952. Two types of basophils in rat pituitaries: thyrotrophs and gonadotrophs vs.

HAMMOND, J. beta and delta cells. Endocrinology 50:140.

1927. The physiology of reproduction in the cow. Cambrilge Univ. Press.

HANCOCK, J. L.

1949a. Evidence of an inherited seminal characteristic associated with infertility of Friesian bulls. Veterinary Rec. 61:308-09.

1949b. A seminal defect associated with sterility in Guernsey bulls. Veterinary Rec. 61:742-43.

JubB, K. V., and K. MCENTEE

1955a. Observations on the bovine pituitary gland. I. Review of literature on the general problem of adenohypophyseal functional cytology. Cornell Veterinarian 45:576-92.

$1955 b$. Observations on the bovine pituitary gland. II. Architecture and eytology with special reference to basophil cell function. Cornell Veterinarian 45:593-641.

Lostroh, A. J., P. G. Squire, and C. H. LI

1958. Bioassay of ICSH in the hypophysectomized male rat by the ventral prostate test. Endocrinology 62:833-42. 
MANN, T.

1948. Fructose content and fructolysis in semen: practical application in evaluation of semen quality. Jour. Agr. Sci. 38:323.

Maximow, A. A., and W. Bloom

1957. A textbook of histology. 7th ed. W. B. Saunders Company.

Mixner, J. P., H. L. SAUnders, and J. E. Johnston

1957. Study of some chromogens in cow urine. Jour. Dairy Sci. 40:67-74.

Moss, S., J. F. SYKES, and T. R. WRENN

1956. Some abnormalities of the bovine endometrium. Jour. Animal Sci. 15:631-39.

Moss, S., T. R. WRENN, and J. F. SYkeS

1954. Alkaline phosphatase, glycogen and PAS positive substances in the bovine uterus during the estrous eycle. Endocrinology 55:261-73.

Purves, H. D., and W. E. Griesbach

1951. The site of thyrotrophin and gonadotrophin production in rat pituitary studied by McManus-Hotchkiss staining for glycoprotein. Endocrinology 49:244.

1954. The site of LH and FSH production in rat pituitary. Endocrinology 55:785.

1955. Changes in the gonadotrophs of the rat pituitary after gonadectomy. Endocrinology $56: 374$.

REECE, R. P., and C. W. TURNER

1937. The lactogenic and thyrotropic content of the anterior lobe of the pituitary gland. Missouri Agr. Exp. Sta. Res. Bul. 266:28-73.

Ross, G. T., R. C. BAHN, and R. W. SCHMIT

1958. Gonadotrophic activity of the periodic acid-Schiff reactive material on anterior pituitary "basophils" of normal rats. Paper No. 48, Program of the 40th meeting "The Endocrine Society."

SAFFran, M., and O. F. DenstedT

1948. Determination of citric acid. Jour. Biochem.175:849-55.

Segaloff, A., S. L. Steelman, and A. Flores

1956. Prolactin as a factor in the ventral prostate assay for luteinizing hormone. Endocrinology 59:233-40.

Severinghaus, A. E.

1932. A cytological technique for the study of the anterior lobe of the hypophysis. Anatomical Rec. 53:1-5.

Steelman, S. L., and F. M. Pohley

1953. Assay of FSH based on the augmentation with H.C.G. Endocrinology 53:604-16.

Tanabe, T. Y., and J. O. Almquist

1953. Some causes of infertility in dairy heifers. Jour. Dairy Sci. 36:586.

TANABE, T. Y., and L. E. CASIDA

1949. The nature of reproductive failures in cows of low fertility. Jour. Dairy Sci. 32:237.

Wiltbank, J. N., W. J. Tyler, and L. E. Casida

1953. A study of atretic follicles in six-sire groups of Holstein-Friesian cattle. Jour. Dairy Sci. 36:1077-82. 
The journal Hilgardia is published at irregular intervals, in volumes of about 600 pages. The number of issues per volume varies.

Subscriptions are not sold. The periodical is sent as published only to libraries, or to institutions in foreign countries having publications to offer in exchange.

You may obtain a single copy of any issue free, as long as the supply lasts; please request by volume and issue number from:

\section{Agricultural Publications}

207 University Hall

2200 University Avenue

Berkeley 4, California

The limit to nonresidents of California is 10 separate issues on a single order. A list of the issues still available will be sent on request. 